\title{
"The effect of age and gender on financial risk tolerance of South African investors"
}

\begin{tabular}{|c|c|}
\hline AUTHORS & $\begin{array}{l}\text { Zandri Dickason (D https://orcid.org/0000-0002-3157-7772 } \\
\text { Sune J. Ferreira (D https://orcid.org/0000-0002-3112-4132 }\end{array}$ \\
\hline ARTICLE INFO & $\begin{array}{l}\text { Zandri Dickason and Sune J. Ferreira (2018). The effect of age and gender on } \\
\text { financial risk tolerance of South African investors. Investment Management and } \\
\text { Financial Innovations, 15(2), 96-103. doi:10.21511/imfi.15(2).2018.09 }\end{array}$ \\
\hline DOI & http://dx.doi.org/10.21511/imfi.15(2).2018.09 \\
\hline RELEASED ON & Friday, 11 May 2018 \\
\hline RECEIVED ON & Thursday, 11 January 2018 \\
\hline ACCEPTED ON & Thursday, 26 April 2018 \\
\hline LICENSE & $\begin{array}{l}(c)) E Y \\
\text { This work is licensed under a Creative Commons Attribution } 4.0 \text { International } \\
\text { License }\end{array}$ \\
\hline JOURNAL & "Investment Management and Financial Innovations" \\
\hline ISSN PRINT & $1810-4967$ \\
\hline ISSN ONLINE & $1812-9358$ \\
\hline PUBLISHER & LLC "Consulting Publishing Company "Business Perspectives" \\
\hline FOUNDER & LLC "Consulting Publishing Company "Business Perspectives" \\
\hline$\sigma^{0}$ & $\begin{array}{l}\text { 三ニ } \\
\text { 三こ }\end{array}$ \\
\hline NUMBER OF REFERENCES & NUMBER OF FIGURES \\
\hline 35 & 5 \\
\hline
\end{tabular}

(c) The author(s) 2022. This publication is an open access article. 


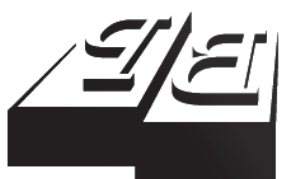

BUSINESS PERSPECTIVES

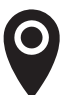

LLC "CPC "Business Perspectives" Hryhorii Skovoroda lane, 10, Sumy, 40022, Ukraine

www.businessperspectives.org

Received on: $11^{\text {th }}$ of January, 2018 Accepted on: $26^{\text {th }}$ of April, 2018

(C) Zandri Dickason,

Sune J. Ferreira, 2018

Zandri Dickason, Ph.D., Lecturer, North West University, Vanderbijlpark, South Africa.

Sune J. Ferreira, Master degree, Lecturer, North West University, Vanderbijlpark, South Africa.

\section{(ㄷ)(ㄱ)}

This is an Open Access article, distributed under the terms of the Creative Commons Attribution 4.0 International license, which permits unrestricted re-use, distribution, and reproduction in any medium provided the original work is properly cited.
THE EFFECT OF AGE

AND GENDER ON FINANCIAL RISK TOLERANCE OF SOUTH AFRICAN INVESTORS

\begin{abstract}
Financial risk tolerance refers to the amount of risk a person is willing to take when making financial decisions. Previous researchers have found that demographic factors when used as independent variables to have an effect on the risk tolerance behavior of investors. Within this study, emphasis was given to gender and age within a sample of South African investors. Not much research on risk tolerance and demographics has been done in South Africa. Hence, an opportunity for further research within this field emerged. This study aimed to contribute towards the accurate risk profiling of South African investors based on their level of risk tolerance considering their gender and age. This study can be used as a future forecasting tool for investment companies to predict risk tolerance levels based on gender and age levels. Results from this study correspond to previous studies where male investors are more risk tolerant than female investors. A statistical difference was also found between male and female investors within the age categories of 35-49 years and investors older than 50 years. All age categories were found to be more risk tolerant for investors older than 50 years based on the binary regression.
\end{abstract}

\section{Keywords risk tolerance, investors, logistic regression, gender, age}

\section{JEL Classification G23, J16, J14}

\section{INTRODUCTION}

Risk tolerance research with emphasis on demographical factors is limited and yet vital to the financial industry. So many of financial and investor researchers do not portray the actual risks that investors face and may be contradictory research that does not consider the multidimensionality of risk and subjectivity of risk tolerance (MacCrimmon \& Wehrung, 1986).

Various characteristics of demographic variables are to be considered when researching financial risk tolerance such as years leading to retirement, high education levels, race, being self-employed, gender and non-investment income (Sung \& Hanna, 1996). Wang and Hanna (1997) established that there is a relationship between age and risk tolerance. Moreover, Grable and Lytton (1998) found in their research that age and gender were the most important variables influencing risk tolerance along with other characteristics such as marital status, occupation, self-employment, income, race and education. In 1999, Grable and Joo added that high levels of education, financial knowledge, internal locus of control, marital status, professional occupation, high income, solvency and economic expectations are important variables affecting financial risk tolerance. However, Grable and Joo (2000) did not consider gender, age and marital status to be important variables. 
In further studies, Gibson et al. (2013) found that investors that were financial clients had a higher level of risk perception and believed income and that investment knowledge have a positive influence on risk tolerance. However, these researchers believed that gender and age have a negative impact on risk tolerance.

\section{LITERATURE REVIEW}

Many factors impact risk tolerance when investors make investment decisions. Whereas risk tolerance is a dependent variable, other factors are independent variables (Tversky \& Kahneman, 1981). Due to various financial risk tolerance assessment methodologies, it was found that there are demographic, socio-economic, as well as psychological factors that impact financial risk tolerance (Van de Venter et al., 2012; Nguyen, 2015). A person's tolerance highly influences a person's decisionmaking process. Irwin (as cited in Bell \& Bell, 1993, pp. 7-28) developed one of the first models to demonstrate these factors (Table 1). This table also indicates which factors are assumed more tolerant.

Table 1. Factors associated with financial risk tolerance

Source: Irwin (as cited in Bell \& Bell, 1993, pp. 7-28).

\begin{tabular}{|c|c|}
\hline $\begin{array}{l}\text { Individual } \\
\text { characteristics }\end{array}$ & $\begin{array}{c}\text { Assumed } \\
\text { to be more tolerant }\end{array}$ \\
\hline Age & Younger people \\
\hline Education & Bachelor's degree or higher \\
\hline Employment status & Employed full-time \\
\hline Ethnicity & Non-Hispanic white \\
\hline Financial knowledge & High \\
\hline Financial satisfaction & High \\
\hline Gender & Male \\
\hline Home ownership & Owner \\
\hline Household size & Large \\
\hline Income & High \\
\hline Income source & Business owner \\
\hline Income variability & Stable and predictable \\
\hline Locus of control & Internal \\
\hline Marital status & Single \\
\hline Marital/gender interaction & Single male \\
\hline Mood & Happy \\
\hline Net worth & High \\
\hline Occupation & Professional \\
\hline Personality & Type A \\
\hline Religiosity & Less religiosity \\
\hline Self-esteem & High \\
\hline Sensation seeking & High \\
\hline
\end{tabular}

From Table 1 it can be concluded that individual characteristics influence the risk tolerance levels of investors, as well as which factors are assumed to be more tolerant. Figure 1 presents a graphic presentation of a conceptual model of the main principal factors affecting risk tolerance, namely biopsychosocial, environmental and precipitating factors.

The abovementioned factors can lead to increased or decreased levels of risk tolerance affecting a person's decision to change, adapt or terminate a risky behavior. Sadiq and Ishaq (2014) stated that investor decisions are influenced by demographic factors on investor's level of risk tolerance. Grable (2016) emphasized although an investor might not have control over demographical factors, environmental factors may affect financial decisions due to influences from the social environment. This is important as a supportive environment is part of a person's life and helps to understand and shape investment behavior. Both biopsychosocial and environmental factors play a role in a person's financial risk tolerance. Moreover, precipitating factors are found to also influence risk tolerance levels. These factors typically have an influence on a person's risk assessment as this impacts the decisionmaking process leading a person to modify and adjust risk tolerance levels and behavior (Grable, 2016).

The age factor in investor risk tolerance has been investigated widely as this relates to a person's ability to measure financial losses. Older investors have less time to recoup or recover financial losses (Grable \& Lytton, 1998). The first researchers to investigate the relationship between risk tolerance and age were Wallach and Kogan (1961). These researchers found that older people were reluctant and cautious to take risks in financial decisions.

Moreover, researchers that found a positive relationship between age and risk tolerance were Botwinick (1966), Vroom and Pahl (1971), Baker and Haslem (1974), Okun and DiVesta (1976), Morin and Suarez (1983), Hawley and Fuji (1993), Wang and Hanna (1997), Grable (2000) and Van de Venter et al. (2012). These researchers found that older people tend to be more risk tolerant 


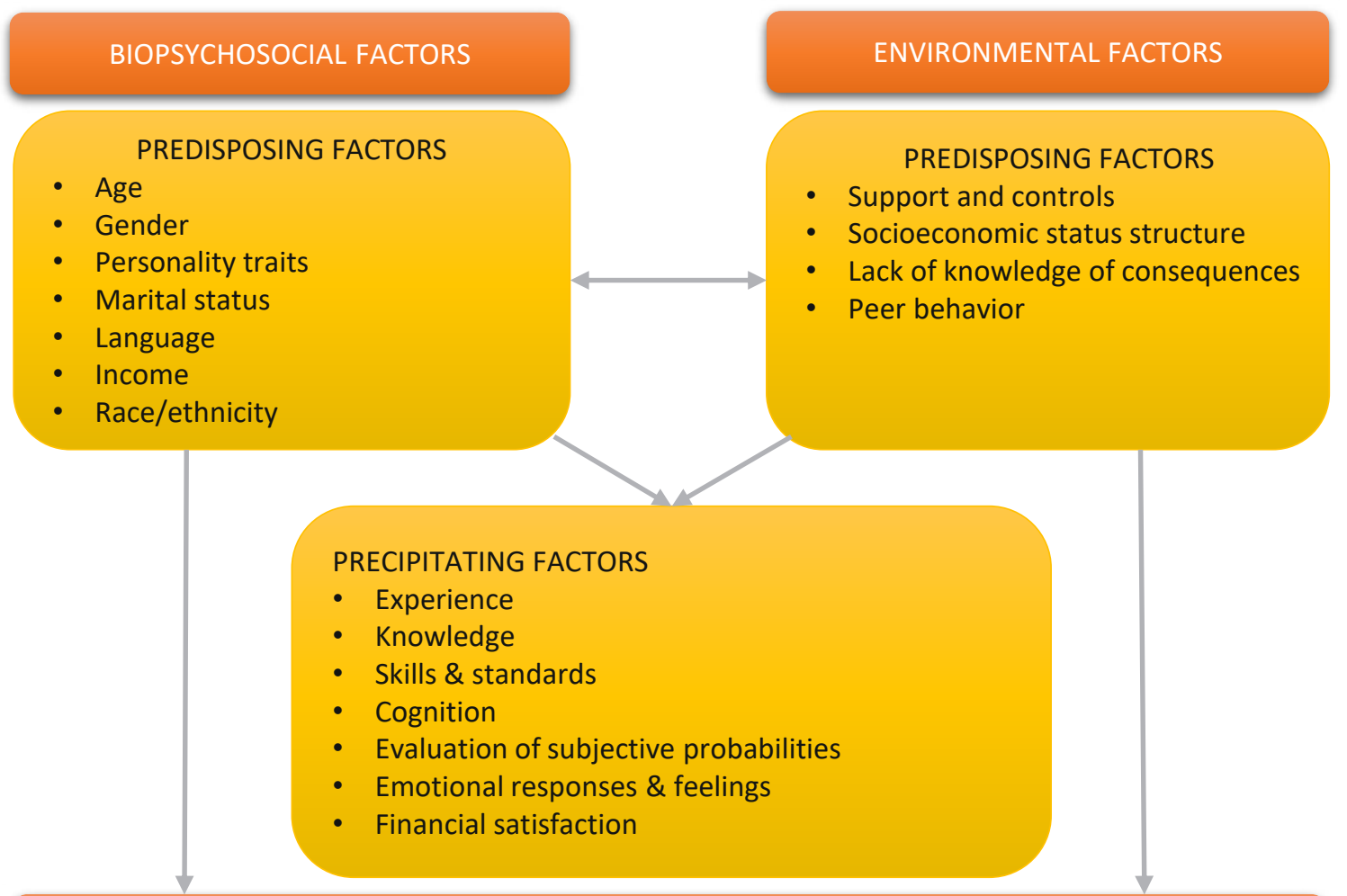

FINANCIAL RISK TOLERANCE

Figure 1. Conceptual model of principal factors affecting financial risk tolerance

based on binary regression results. However, some researchers such as Sung and Hanna (1996), and Grable and Joo (1999) reported no significant relationship between age and risk tolerance. ClarkMurphy et al. (2009) proved that as investors' age increases, it might lead to higher investment returns. Anbar and Eker (2010) also held the view that there is no significant relationship between age and risk tolerance. Cutler (1995) researched financial risk tolerance and concluded that risk tolerance is a one-dimensional attitude. Regardless of different opinions, it was found that researchers must consider age as an influential factor of investor risk tolerance. As the rate of risk tolerance tends to decrease more as people get older, it influences financial decision-making, investment choices and behavior.

Previous studies conducted emphasize the important role of gender as a factor that influence risk tolerance (Higbee \& Lafferty, 1972; Blume, 1978; Coet \& McDermott, 1979; Rubin \& Paul, 1979; Yip, 2000). The most known finding is that male investors tend to take more risks than female investors
(Sung \& Hanna, 1996). The primary objective of this study is to determine whether age and gender play a role in the level of financial risk tolerance South African investors are willing to take and whether there is a difference between males and females in comparison with their age groups. The contribution of this paper is to profile investors based on gender and age in specific financial risk levels.

\section{METHODOLOGY}

The following sections within the methodology represent the research approach and instrument used, the sample size, formulated hypothesis and statistical analysis.

\subsection{Research instrument}

For this study, a quantitative research approach was implemented using a questionnaire consisting of two sections. The first section was aimed at collecting the demographic information of investors 
whereby age and gender was used for the purpose of this study. Furthermore, the second section implemented a validated risk tolerance question namely Survey of Consumer Finance (SCF) where an idiosyncratic risk tolerance question was asked. The single risk tolerance question is the only direct measure of risk attitude within the SCF (Gilliam et al., 2010).

The single risk tolerance question is represented by the following question: "Which of the following statements comes closest to the amount of financial risk that you and your (husband/wife/partner) are willing to take when you save or make investments?"

1. Take substantial financial risks expecting to earn substantial returns.

2. Take above average financial risks expecting to earn above average returns.

3. Take average financial risks expecting to earn average returns.

4. Not willing to take any financial risks.

The distinct risk tolerance question allowed participants to only select the most relevant option. As in previous research studies, the answer options were reverse coded where options one and two was deemed as more risk tolerant and options three and four less risk tolerant (Grable \& Lytton, 2001).

\subsection{Research sample selection}

In order to reach South African investors, a South African investment company was used to collect the sample data for this study. Hence, this study made use of non-probability convenience sampling by using an investment company that has access to South African investors. From the South African investor population, a random sample was selected to ensure unbiasedness. The final sample included 600 investors from an investment company $(n=600)$. Participants received an online questionnaire to complete out of own free will. Table 2 represents the gender frequencies of the sample, as well as the age distribution of the sample.
Table 2. Demographic information of the sample

\begin{tabular}{l|c|c|c}
\hline Variable & Category & Frequency & Percentage (\%) \\
\hline \multirow{2}{*}{ Gender } & Male & 256 & 42.70 \\
& Female & 344 & 57.30 \\
& $16-34$ & 150 & 25.00 \\
Age & $35-49$ & 220 & 26.70 \\
& $50+$ & 230 & 38.30 \\
Total & & 600 & 100.00 \\
\hline
\end{tabular}

Referring to the demographic information in Table 2, more than half of the participants were females $(57.30 \%)$, while the remaining percentage (42.70\%) represented male participants. Age distribution indicated that the majority of the participants $(38.30 \%)$ were over 50 years of age with the oldest participant being 85 years old. Following this age category was the $35-49$ years age category representing $26.70 \%$ of the sample. The remaining percentage were investors between the ages of 16 34 years $(25.00 \%)$.

\subsection{Hypothesis}

Based on the background of the study, previous researchers found a difference between the risk tolerance levels of males and females and between different age groups. The following hypothesis were formulated to research the primary objective of this study:

$H_{0}$ : mean of male risk tolerance within age group $=$ mean of female risk tolerance withn in age group.

The abovementioned hypothesis suggests that no difference exist between male and female investors' risk tolerance levels within different age categories.

\subsection{Statistical analysis}

This study made use of descriptive statistics such as cross tabulations, as well as logistic regression to test how risk tolerance between males and females within each age category differs. The following equation presents the estimated logistic regression:

$$
S C F_{i}=\beta_{0}+\beta_{1} G E N+\beta_{2} A G E+\mu_{1} .
$$

The dependant variable was created using the SCF risk tolerance question, where $S C F_{i}$ presents de- 
Table 3. Cross tabulation of investor risk tolerance of gender and age

\begin{tabular}{|c|c|c|c|c|c|c|}
\hline \multirow[b]{2}{*}{ Variable } & \multirow[b]{2}{*}{ Category } & \multicolumn{4}{|c|}{ Risk tolerance level of investors } & \multirow[b]{2}{*}{$\begin{array}{l}\text { Pearson } \\
\text { Chi-square }\end{array}$} \\
\hline & & $\begin{array}{c}\text { Not willing to } \\
\text { take any risk }\end{array}$ & $\begin{array}{c}\text { Take average } \\
\text { risk }\end{array}$ & $\begin{array}{c}\text { Take above } \\
\text { average risk }\end{array}$ & $\begin{array}{c}\text { Take substantial } \\
\text { risk }\end{array}$ & \\
\hline \multirow{2}{*}{ Gender } & Male & 14.50 & 42.20 & 31.60 & 11.70 & \multirow{2}{*}{$0.000 *(23.931)$} \\
\hline & Female & 27.00 & 45.90 & 18.90 & 8.10 & \\
\hline \multirow{3}{*}{ Age } & $16-34$ & 13.30 & 46.60 & 26.70 & 14.00 & \multirow{3}{*}{$0.001 *(23.208)$} \\
\hline & $35-49$ & 24.50 & 36.40 & 28.20 & 10.90 & \\
\hline & $50+$ & 24.30 & 50.90 & 19.10 & 5.70 & \\
\hline
\end{tabular}

Note: ${ }^{*}$ Significant at $1 \%$ level.

pendant variable - the risk tolerance level of South African investors ( 1 for substantial risk tolerance and 0 for low risk tolerance). By using the SCF measure of risk tolerance as the dependant variable, previous researchers have found demographic factors such as age and gender to have an effect on individual risk tolerance (Grable \& Lytton, 2001). The equation presents the following: $\beta_{0}$ represents the constant; $\beta_{1}$ and $\beta_{2}$ is the coefficients and $\mu_{1}$ gives the error term. Two independent variables were created where $\beta_{1} G E N$ was given as the gender of investors ( 1 for males and 0 for female); $\beta_{2} A G E$ presents the age of the individual investors $(1=16-34,2=35-49,3=50+)$.

\section{EMPIRICAL RESULTS AND DISCUSSION}

\subsection{Investor risk tolerance according to gender and age}

Table 3 reflects the cross tabulation of the various levels of investor risk tolerance according to their gender and age.
The high Chi-square value (23.931) with a $p$-value 0.000 between gender and SCF is indicative of a statistical difference between the risk tolerance level of males and females within the sample. Within the sample males are more likely to take above average risk $(31.60 \%)$ to earn above average returns compared to female investors (18.90\%). Considering the age distribution, investors within the age category of 50 years and older was more likely to take average risk (50.90\%) than younger investors between the age of $35-49$ years $(36.40 \%)$ and $16-34$ years $(46.60 \%)$. The majority of young investors between the ages of 16-34 years tend to take more average risk $(46.60 \%)$ or no risk at all (13.30\%) indicating that more than half (59.90\%) of the young investors are low risk tolerant. Only 40.7 percent of young investors (16-34) were willing to take above average risk and substantial risk. These results are the exact opposite of the general investor lifecycle theory stating that younger investors should be more willing to take on higher risk (Bodie et al., 2007). Several reasons for the lower risk tolerance in younger investors exist. Firstly, although younger investors tend to take on more risk, it does not always lead to higher returns and will ultimately lead to lower risk toler-

Table 4. Comparing male and female investors within age categories

\begin{tabular}{|c|c|c|c|c|c|c|}
\hline \multirow[b]{2}{*}{ Variable } & \multirow[b]{2}{*}{ Category } & \multicolumn{4}{|c|}{ Risk tolerance level of investors } & \multirow{2}{*}{$\begin{array}{l}\text { Pearson } \\
\text { Chi-square }\end{array}$} \\
\hline & & $\begin{array}{l}\text { Not willing to } \\
\text { take any risk }\end{array}$ & $\begin{array}{c}\text { Take average } \\
\text { risk }\end{array}$ & $\begin{array}{l}\text { Take above } \\
\text { average risk }\end{array}$ & $\begin{array}{c}\text { Take substantial } \\
\text { risk }\end{array}$ & \\
\hline \multirow{2}{*}{ Age 16-34 } & Male & 5.80 & 44.20 & 28.80 & 21.20 & \multirow{2}{*}{$0.089(6.521)$} \\
\hline & Female & 17.30 & 46.90 & 25.50 & 10.20 & \\
\hline \multirow{2}{*}{ Age $35-49$} & Male & 17.30 & 28.40 & 40.70 & 13.60 & \multirow{2}{*}{$0.05^{* *}(13.006)$} \\
\hline & Female & 28.80 & 41.00 & 20.90 & 9.40 & \\
\hline \multirow{2}{*}{ Age 50+ } & Male & 16.30 & 50.40 & 26.80 & 6.50 & \multirow{2}{*}{$0.01 *(15.645)$} \\
\hline & Female & 33.60 & 51.40 & 10.30 & 4.70 & \\
\hline
\end{tabular}

Note: ${ }^{*}$ Significant at $1 \%$ level, ${ }^{* *}$ significant at $5 \%$ level. 
ance levels (Sultana, 2010). Secondly, while young investors are still in the accumulation phase, some might have a longer time horizon (20-30 years), which will also lead to lower risk tolerance levels, since there are no immediate need for excessive returns (Yao et al., 2011).

Hence, the comparison between the risk tolerance levels of the different age groups suggests a statistical difference between age categories 16-34 years, $35-49$ years and $50+$ years with a high Chi-square value of 23.208 and a $p$-value of 0.001 .

As seen in Table 4, a significant statistical difference at $5.00 \%$ exist between the risk tolerance level of males and females within the age category of 35-49 years. Within this age category males were more likely to take on above average risk (40.70\%) compared to female investors (20.90\%). A statistical difference also exist between males and females within the $50+$ age group where females $(33.60 \%)$ are not willing to take on any risk compared to $16.30 \%$ of male investors. No statistical significant difference exist between male and female investors within the ages of 16-34 ( $p$-value > 0.05).

\subsection{Regression analysis}

Table 5 indicates the results found for the logistic regression considering the influence of gender and age on the financial risk tolerance levels of South African investors.

The Omnibus test for model coefficients proved to be significant at $1.00 \%$ considering $p$-value $<0.01$ with a Chi-square value of 39.395 . This implies that the new model is significantly better and passed the goodness fit model. Furthermore, the Hosmer \& Lemeshow test of the goodness fit suggests that this model is a good fit for the data as $p$-value $=0.888$, which is greater than the 0.05 significance level. The Nagelkerke $R$-squared test also suggests that the model coefficients explained $8.80 \%$ of the variation in the dependant variable. The relatively low Nagelkerke $R$-squared is indicative of that only two demographical factors namely age and gender was used to explain the variation in the risk tolerance level of investors. In the binary logistic regression, three age groups were entered with the 50+ age category as the reference group.

The results in Table 5 indicates that male investors were more likely to be high risk tolerant than female investors, since a positive coefficient (Beta $=0.904)$ was observed for gender. The statise tically significant $p$-value (0.000) for gender infers that the null hypothesis can be rejected at a $1.00 \%$ level of significance. This indicates that there is indeed a difference between male and female investors in terms of their risk tolerance levels. The odds ratio of 2.469 specifies that $(2.469-1)$ male investors are $146.90 \%$ more likely to be high risk tolerant compared to female investors. These results concurs with previous research done by Slovic (1966), as well as Sung and Hanna (1996) who indicated that in some cultures it was believed that males tend to take greater risks than females.

For the age category 16-34 years it is found that this group of investors are more likely (positive coefficient) to be higher risk tolerant than investors older than 50 years. Investors within this category are $(2.562-1)$ are $156.20 \%$ more likely to be high risk tolerant than older investors. This concludes that the null hypothesis can be rejected. A positive coefficient was also found for the age category 3549 years indicating that this age category are more likely to be high risk tolerant than investors over the age of 50 .

Table 5. Binary logistic regression analysis

\begin{tabular}{|c|c|c|c|c|c|c|}
\hline Variable & Beta & Std. Error & Wald & df & Sig. & Odds ratio \\
\hline Gender & 0.904 & 0.184 & 24.132 & 1 & $0.000 *$ & 2.469 \\
\hline $16-34$ & 0.941 & 0.236 & 15.889 & 1 & $0.000^{*}$ & 2.562 \\
\hline $35-49$ & 0.851 & 0.215 & 15.686 & 1 & $0.000^{*}$ & 2.343 \\
\hline $50+$ & - & - & - & 2 & $0.000^{*}$ & - \\
\hline \multicolumn{3}{|c|}{-2 Log likelihood 729.848} & \multicolumn{4}{|c|}{ Omnibus test 39.395} \\
\hline \multicolumn{3}{|c|}{ Hosmer \& Lemeshow 1.142 p-value (0.888) } & \multicolumn{4}{|c|}{ P-value 0.000} \\
\hline
\end{tabular}

Note: ${ }^{\star}$ Significant at $1 \%$ level. 
The $p$-value $(0.000)$ for the age category of $50+$ years concludes that the null hypothesis (coefficients $=0)$ can be rejected at a $1.00 \%$ level of sige nificance. This indicates that there is indeed a difference between the risk tolerance level amongst investors within different age categories. It can be assumed that young investors have more years to recover from financial losses due to risky investments based on the binary regression results. Cutler (1995) researched financial risk tolerance and concluded that the rate of risk tolerance tends to decrease more as people get older.

\section{CONCLUSION}

Previous researchers have found that demographical factors when used as independent variables have an effect on the risk tolerance of investors. Within this study, emphasis was given to gender and age within a sample of South African investors. Not much research on risk tolerance and demographics have been done in South Africa. Hence, an opportunity for further research within this field emerged. This study aimed to contribute towards the accurate risk profiling of South African investors based on their level of risk tolerance considering their gender and age. Results indicated that a difference does exist not only between male and female investors, but also within different age groups. It can be assumed that young investors have more time to recover from financial losses and, as a result, would be willing to take on more risks based on the binary regression results. However, cross tabulation indicated that majority of young investors were not willing to take on any risk or just average risk. This could be due to the failure to accept excessive risk or due to longer time horizons. Investment companies could therefore also suggest investments within an average risk category. Moreover, male investors tend to take on more risks than female investors, which is concurrent with previous studies. In the various age categories, male investors are willing to take more substantial risks compared to female investors. Hence the null-hypothesis was rejected for two of the three age groups. This will significantly contribute towards the risk profiling of investors to accurately invest according to a specific risk tolerance level.

\section{REFERENCES}

1. Anbar, A., \& Eker, M. (2010). An empirical investigation for determining of the relations between personal financial risk tolerance and demographic characteristics. Ege Academic Review, 10(2), 503-523. Retrieved from https://papers.ssrn.com/sol3/ papers.cfm?abstract_id=1732236

2. Baker, H. K., \& Haslem, J. A. (1974). The impact of investor socio-economic characteristics on risk and return preferences. Journal of Business Research, 2(1), 469-476. https://doi. org/10.1016/0148-2963(74)90032-0

3. Blume, M. (1978). The changing role of the individual investor. New York: John Wiley \& Sons. https:// doi.org/10.2307/1057448

4. Bodie, Z., Kane, A., \& Marcus, A. J. (2007). Essentials of investments (2nd ed.). New York: McGraw-Hill.

5. Botwinick, J. (1966). Cautiousness in advanced age. Journal of Gerontology, 21(3), 347353. https://doi.org/10.1093/ geronj/21.3.347

6. Clark-Murphy, M., Gerrans, P., \& Speelman, C. (2009). Return chasing as a driver in individual retirement savings investment choices: evidence from Australia. Journal of Family Economics Issue, 30(1), 4-19. https://doi. org/10.1007/s10834-008-9133-8

7. Coet, L. J., \& McDermott, P. J. (1979). Sex, instructional set, and group make-up: orgasmic and situational factors influencing risk-taking. Psychological Reports, 44(1), 1283-1294. https://doi. org/10.2466/pr0.1979.44.3c.1283

8. Cutler, N. E. (1995). Three myths of risk-tolerance: what clients are not telling you. Journal of the American Society of CLU \& ChFC, 49(1), 33-37.

9. Gibson, R., Michayluk, D., \& Van de Venter, G. (2013). Financial risk tolerance: an analysis of unexplored factors. Financial Services Review, 22(1), 23-50. Retrieved from https://opus.lib. uts.edu.au/handle/10453/23532

10. Gilliam, J., Chatterjee, S., \& Grable, J. E. (2010). Measuring the perception of financial risk tolerance: a tale of two measures. Journal of Financial Counselling and Planning, 21(2), 30-43. Retrieved from https://papers.ssrn. com/sol3/papers.cfm?abstract_ $\mathrm{id}=2061313$

11. Grable, J. E., \& Joo, S. (1999). Factors related to risk tolerance: a further examination. Consumer Interests Annual, 45(1), 53-58. Retrieved from http://www.consumerinterests.org/assets/docs/ cia1999/grablejoo.pdf

12. Grable, J. E., \& Joo, S. (2000). A cross-disciplinary examination of financial risk tolerance. Consumer Interests Annual, 
46(2), 151-157. Retrieved from https://www.researchgate.net/ publication/288864378_A_crossdisciplinary_examination_of_financial_risk tolerance

13. Grable, J. E., \& Lytton, R. H. (1998). Investor risk tolerance: testing the efficacy of demographics as differentiating and classifying factors. Financial Counselling and Planning, 9(1), 61-73. Retrieved from https://papers.ssrn.com/sol3/ papers.cfm?abstract_id $=132598$

14. Grable, J. E., \& Lytton, R. H. (2001). Assessing the concurrent validity of the SCF risk tolerance question. Journal of Financial Counselling and Planning, 12(2), 43-53. Retrieved from https://www.researchgate. net/publication/253696181_Assessing_The_Concurrent_Validity_Of_The_SCF_Risk_Tolerance Question

15. Grable, J. E. (2000). Financial risk tolerance and additional factors that affect risk taking in everyday money matters. Journal of Business and Psychology, 14(2), 625-630. Retrieved from https://link.springer.com/ article/10.1023/A:1022994314982

16. Grable, J. E. (2016). Financial risk tolerance. Switzerland: Springer.

17. Hawley, C. B., \& Fuji, E. T. (1993). An empirical analysis of preferences for financial risk: further evidence on the Friedman-Savage model. Journal of Post Keynesian Economics, 16(1), 197-204. Retrieved from https://www.jstor.org/ stable/4538385?seq=1\#page_scan_ tab_contents

18. Higbee, K. L., \& Lafferty, T. (1972). Relationships among risk preferences, importance, and control. The Journal of Psychology, 81(1), 249-251. https://doi.org/10.1 080/00223980.1972.9916946

19. Irwin, C. E. (1993). Adolescence and risk taking: How are they related? In N. J. Bell \& R. W. Bell (Eds.), Adolescent risk taking (pp. 7-28). Newbury Park, CA: SAGE. Retrieved from https:// www.researchgate.net/publication/232500007_Adolescence_ and_risk-taking_How_are_they_ related
20. MacCrimmon, K. R., \& Wehrung, D. A. (1986). Risk management. New York: The Free Press.

21. Morin, R. A., \& Suarez, F. (1983). Risk aversion revisited. The Journal of Finance, 38(1), 1201-1216. Retrieved from https://www.jstor. org $/$ stable $/ 2328020$ ?seq=1\#page scan_tab_contents

22. Nguyen, T. M. L. (2015). The influence of financial risk tolerance and risk perception on individual investment decisions-making in a financial advice context (Ph.D. Thesis, Queensland University).

23. Okun, M. A., \& DiVesta, F. J. (1976). Cautiousness in adulthood as a function of age and instructions. Journal of Gerontology, 31(1), 571576. https://doi.org/10.1093/ geronj/31.5.571

24. Rubin, P. H., \& Paul, C. W. (1979). An evolutionary model of tastes for risk. Economici Inquiry, 17(4), 585-596. Retrieved from http:// www.economics-ejournal.org/economics/journalarticles/2012-24/ references/RePEc-oup-ecinqu-v17-y-1979-i-4-p-585-96/bibliography_entry_view

25. Sadiq, M. N., \& Ishaq, H. (2014). The effect of demographic factors on the behaviour of investors during the choice of investment: evidence from twin cities of Pakistan. Global Journal of Management and Business Research, 14(3), 1-11. Retrieved from https://globaljournals.org/ GJMBR_Volume14/7-The-Effectof-Demographic-Factors.pdf

26. Slovic, P. (1966). Risk-taking in children: age and sex differences. Child Development, 37(4), 169-176. https://doi.org/10.2307/1126437

27. Sultana, S. T. (2010). An empirical study of Indian individual investors' behaviour. Global Journal of Finance and Management, 2(1), 19-33. Retrieved from http://docshare01.docshare.tips/ files/3651/36516864.pdf

28. Sung, J., \& Hanna, S. (1996). Factors related to risk-tolerance. Financial Counselling and Planning, 7(2), 11-20. Retrieved from https://papers.ssrn.com/sol3/ papers.cfm?abstract_id=8284
29. Tversky, A., \& Kahneman, D. (1981). The framing of decisions and the psychology of choice. Science, New Series, 211(4481), 453-458. Retrieved from https:// www.uzh.ch/cmsssl/suz/dam/ jcr:ffffffff-fad3-547b-ffffffffe54d58af/10.18_kahneman_ tversky_81.pdf

30. Van de Venter, G., Michayluk, D., \& Davey, G. (2012). A longitudinal study of financial risk tolerance. Journal of Economic Psychology, 33(1), 794-800. https://doi. org/10.1016/j.joep.2012.03.001

31. Vroom, V. H., \& Pahl, B. (1971) Relationship between age and risk taking among managers. Journal of Applied Psychology, 55(2), 399405. http://dx.doi.org/10.1037/ h0031776

32. Wallach, M. A., \& Kogan, N. (1961). Aspects of judgment and decision making: interrelationships and changes with age. Behavioral Science, 6(1), 23-26. https://doi. org/10.1002/bs.3830060104

33. Wang, H., \& Hanna, S. (1997). Does risk tolerance decrease with age? Financial Counselling and Planning, 8(2), 27-32. Retrieved from https://afcpe.org/assets/pdf/ vol824.pdf

34. Yao, R., Sharpe, D. L., \& Wang, F. (2011). Decomposing the age effect on risk tolerance. The Journal of Socio-Economics, 40(6), 879-887. https://doi.org/10.1016/j.socec.2011.08.023

35. Yip, U. Y. (2000). Financial risk tolerance: a state or a trait? (Master's Thesis, University of New South Wales) 